\title{
Notes on the genus Buchwaldoboletus in Galicia and North of Portugal (II). Buchwaldoboletus pontevedrensis, sp. nov.
}

\author{
Blanco-Dios JB ${ }^{1}$ \\ ${ }^{1}$ Centro de Formación e Experimentación Agroforestal de Lourizán. Consellería de Medio Rural. Xunta de Galicia. \\ P.O. Box 127. 36080 Pontevedra, Spain
}

Blanco-Dios JB 2013 - Notes on the genus Buchwaldoboletus in Galicia and North of Portugal (II). Buchwaldoboletus pontevedrensis, sp. nov. Mycosphere 4(5), 945-950, Doi 10.5943/mycosphere/4/5/7

\begin{abstract}
Buchwaldoboletus pontevedrensis, found in Galicia (NW of Spain), is described as a new species based on morphological data. Morphological description, drawings of microscopic characters and color pictures of the basidiomata are presented. A discussion about other close taxa is also outlined.
\end{abstract}

Key words - Basidiomycota - Boletales - Buchwaldoboletus - Spain - taxonomy

\section{Introduction}

Buchwaldoboletus Pilat is a small genus of Boletaceae of about a dozen taxa with a worldwide distribution. This genus is a useful morpho-genus since it unites species with similar characteristic: lignicolous habit, small spores, predominantly yellow to brownish colors, bluing in some parts, and yellow mycelium (Ortíz-Santana \& Both 2011).

Watling \& Hills (2005) proposed two stirps for the two species of Buchwaldoboletus in Europe: Lignicola and Sphaerocephalus. Ortíz-Santana \& Both (2011) proposed a third stirps: Hemichrysus. The stirps Lignicola group is characterized by pileus and stipe tomentose, with some shade of brown, reddish brown, dry, context yellow, bluing, especially above the tubes. This stirps includes the following species: Buchwaldoboletus lignicola (Kallenb.) Pilát (known from Europe and eastern North America), B. xylophilus (Petch) Both \& B. Ortiz (Asia: Sri Lanka, Malaysia, Hong Kong, Philippines), B. kivuensis (Heinem. \& Gooss.-Font.) Both \& B. Ortiz (Africa: Congo), B. brachyspermus (Pegler) Both \& B. Ortiz (Central America: Lesser Antilles, Martinique) and $B$. duckeanus (Singer) Both \& B. Ortiz (South America: Brazil, Amazonia). The stirps Sphaerocephalus has pileus and stipe yellow, pileus silky tomentose, viscid when wet, context bluing and habitat on sawdust of pines, often in enclosed areas. This stirps includes the following species: Buchwaldoboletus sphaerocephalus (Barla) Watling \& T.H. Li (Europe, North America and Southwestern Australia) and B. pseudolignicola (Neda) Both \& B.Ortiz (Asia: Japan). The stirps Hemichrysus is characterized by pileus and stipe bright yellow, pulverulent, pore surface yellow, becoming subferrugineous, stipe yellow above, reddish below. This stirps includes the following taxa: Buchwaldoboletus hemichrysus (Berk. \& M.A.Curtis) Pilát (North America, reports from Europe refer to B. sphaerocephalus), B. acaulis (Pegler) Both \& B. Ortiz (Central America: Lesser Antilles, Martinique); B. parvulus (Natarajan \& Purushothama) Both \& B. Ortiz (Asia: India) and B. spectabilis Watling (Australia, Queensland) (Ortíz-Santana \& Both 2011). 
During a revision of collected material of the genus Buchwaldoboletus of the author (some of his findings have been published (Blanco-Dios \& Tomé Ortega 2011 [2009]), a striking Buchwaldoboletus found under maritime and Monterrey's pines (Pinus pinaster Aiton, Pinus radiata D. Don) has been studied. This taxon was first found in 1989 by the autor and identified by Dr. Luis Freire $(\dagger)$ as Buchwaldoboletus lignicola. In addition, some of the material studied was described in that publication as B. lignicola, but the study of new collections has taken to us to the conclusion that its morphological characters are so different from the known taxa that it is described here as new species.

\section{Materials \& Methods}

The specimens were collected, documented and preserved using standard methods. Morphological descriptions are based on the study of the fresh material and analysis of photographic images obtained from fresh specimens. Macro-chemical reactions were determined using $3 \% \mathrm{KOH}, 10 \% \mathrm{NH}_{4} \mathrm{OH}$ and $10 \% \mathrm{FeSO}_{4}$. Microscopic observations were recorded both from fresh material and dried material with standard methods, using sections mounted in a solution of $1 \%$ Congo red in water, $3 \% \mathrm{KOH}$ or Melzer's reagent. Spore size is presented as (Min) (mean $\mathrm{SD})-($ mean $+\mathrm{SD})(\mathrm{Max})$, where Min= the lowest value measured, Max= the highest value, followed by the mean spore lengths and widths $(\mathbf{X m}) ; \mathbf{Q}=$ spore length : width ratios, and the mean volume ( $\mathbf{V m})$ was determined using the formula $\mathrm{Vm}=4 \pi / 3 \mathrm{a}^{2} \mathrm{~b}$, where $\mathbf{a}$ is the radius of the minor axis and $\mathbf{b}$ the radius of the major axis (Breitenbach \& Kränzlin 1991).

The maximum and minimum values and the length/width ratio (Q) of the pileipellis end cells were determined by sampling between the centre and the margin (Ladurner \& Simonini 2003) in the superior layer of young sporocarps, as recommended by Singer (1965) and Muñoz (2005). Microscopical structures were documented by line drawings on a light microscope equipped with a drawing tube device. The collected material has been deposited in the mycological herbarium LOU-Fungi (Centro de Investigación Forestal de Lourizán, Pontevedra, Spain).

\section{Results}

Buchwaldoboletus pontevedrensis Blanco-Dios, sp. nov.

Figs 1-9 MycoBank 803945 Spain).

Etymology - pontevedrensis, from the municipality and province of Pontevedra (Galicia,

Buchwaldoboletus lignicola similis sed differt pileus 130-198 mm latus, stipes $80-100$ longus, (2,2-) 42-71 mm latus, crassus, ab attenuatus ad radicans, sporis leviter plus grandis, (6.5-) 7.5-10 (-11.2) × (2.8-) 3.5-4.5 (-5) $\mu \mathrm{m}, \mathrm{Xm}=9.3 \times 3.8 \mu \mathrm{m}, \mathrm{Vm}=69 \mu \mathrm{m}^{3}$, ovoideus, ellipsoideus vel ellipticus, cystidiis clavatis, fusiformis, mucronatus, flexuosiformis, lageniformis, utriformis, irregulariter fusiformis vel utriformis, pileipellis ex hyphis trichodermium formantibus, 3-12.5 $\mu \mathrm{m}$ latis, cylindraceis, subcylindraceis vel leviter constrictus, cum elementis terminalis cylindraceis, clavatis, latis clavatis vel irregulariter formis, $14-170 \times 4-15.5 \mu \mathrm{m}, \mathrm{Q}=1.7-24.3$ et caulocystidiis cylindraceis, fusiformis, mucronatus, lageniformis, irregulariter fusiformis vel lageniformis. Super lignum Pinus putridum crescens.

Holotype - SPAIN. Pontevedra: Pontevedra, Bora, 29TNG3397, 120 m, on stump of Pinus pinaster, 10.X.2012, J.B. Blanco-Dios (LOU-Fungi 19573).

Pileus 130-198 mm broad, convex to plane, margin decurved, floccose to felty, slightly viscid, covered with soft appressed tomentum which is easily detersible, attached to the flesh by a thin gelatinous layer, ochre-yellow to ochre-creamy in the margin when young, later ochre-brown to brown, with some shade of pink or purple. Hymenophore tubulose, tubes 1-13 mm long, adnexed with decurrent tooth, yellow, changing to blue when bruised or exposed. Pores $0.5-2 \times$ 0.5-0.75 mm, compressed, irregular, pale yellow when young, becoming bright yellow, golden, golden-ochre or with some shade of brown at maturity, staining blue-grey, intense blue to blueblackish when handled. Stipe $80-100 \times(2,2-) 42-71 \mathrm{~mm}$, usually shorter than the diameter of the 


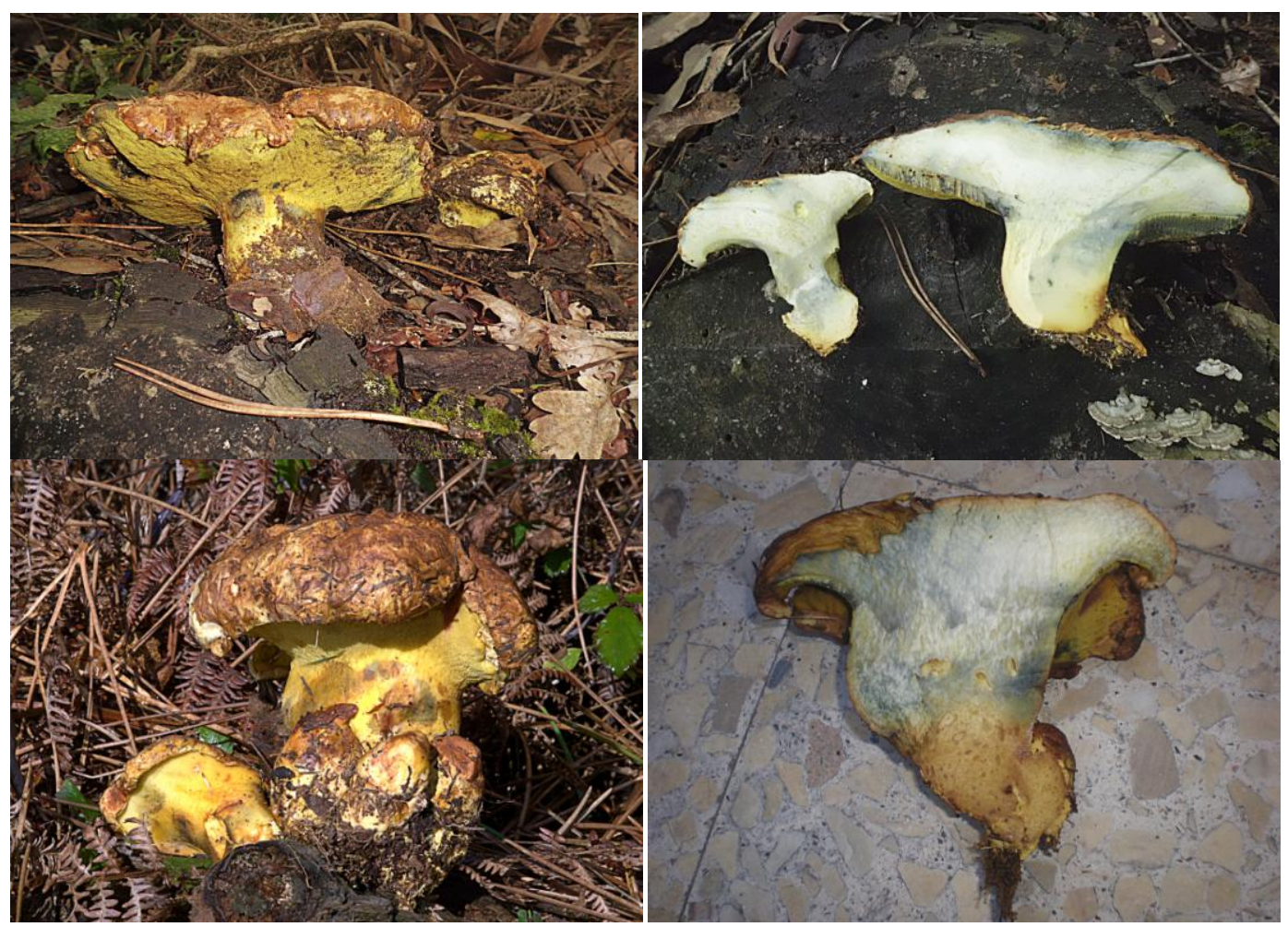

Figs 1-4 - Buchwaldoboletus pontevedrensis. 1-2. Holotype (Pontevedra, Bora). 3-4. Gondomar, Donas.

pileus, robust, curved, attenuate to radicant, with pine bark remains in the base, sulfur yellow with some shade pallid yellow, yellow-orange, golden, ochre, brown, brown-ochre or pink. Stipe surface changes to blue when bruised. Basal mycelium golden-yellow. Context soft in the pileus and firm in the stipe, yellow, changing to pallid blue with some shade of creamy, yellow to ochre when exposed, except under the pileipellis and in the lower part of stipe, pallid yellow, creamy-ochre, yellow-ochre, ochre or brown (with incrusted pine bark), and pinkish above the tubes. A moment later, the shades creamy or yellow (ochre-orange over the tubes) are the colours dominant. Smell very agreeable, sweet-scented. Taste pleasant, slightly acid, with unctuous texture. Edibility unknown. Chemical reactions: $3 \% \mathrm{KOH}$ : dark brown in the pileus, brown-greyish in the flesh of the pileus, brown in the flesh of the stipe; $10 \% \mathrm{NH}_{4} \mathrm{OH}$ : dark brown in the pileus, bottle-green in the flesh of the pileus, pallid green in the flesh of the stipe; $10 \% \mathrm{FeSO}_{4}$ : grey in the flesh of the pileus, dark grey-blackish in the flesh of the stipe. Spore print olive-brown.

Basidiospores (6.5-) 7.5-10 (-11.2) $\times(2.8-)$ 3.5-4.5 (-5) $\mu \mathrm{m}, \mathrm{Xm}=9.3 \times 3.8 \mu \mathrm{m}, \mathrm{Q}=$ (1.8) 1.9-2.8 (3.2), $\mathrm{Vm}=69 \mu^{3},(\mathrm{n}=100)$, ovoid, ellipsoid to elliptic, smooth, guttulate, thickwalled, pallid ochre, ochre-grey or creamy-ochre in $\mathrm{KOH}$, dextrinoid in Melzer's. Basidia 17.5$31.5 \times 5-8.5 \mu \mathrm{m}, 4-$ spored, sterigmata 1-3.5 $\mu \mathrm{m}$ long, clavate or broadly clavate, clampless. Basidioles 15-23.5 × 5.5-7.5 $\mu \mathrm{m}$, clavate. Cystidia 13.5-48 $\times 5-11 \mu \mathrm{m}$, scattered or in clusters, clavate, fusiform, mucronate, flexuous, lageniform, utriform, irregularly fusiform or utriform. Pileipellis an entangled trichodermium of hyphae $3-12.5 \mu \mathrm{m}$ in diameter, cylindric, subcylindric or slightly constricted, multi-septate, subhyaline or grey-creamy in $\mathrm{KOH}$, ochre or brown in Melzer's; end cells $14-170 \times 4-15.5 \mu \mathrm{m}, \mathrm{Q}=1.7-24.3$, cylindrical, clavate, broadly clavate or irregularly shaped, short to elongated. Stipitipellis hyphae $2.5-15 \mu \mathrm{m}$ in diameter, interwoven or subparallel, hyaline, subhyaline or creamy-grey in $\mathrm{KOH}$, cream, ochre or brown in Melzer's. Caulocystidia 13$38 \times 3.5-12 \mu \mathrm{m}$, scattered, cylindric, fusiform, mucronate, lageniform, irregularly fusiform or lageniform. Clamp connections absent. 
Habitat - solitary, two or three (five) specimens fused together. At the base of or on top of stumps of pines (Pinus pinaster and $P$. radiata). (Spain).

Known distribution - up to now known only from three localities in Pontevedra Province

Material examined - SPAIN. Pontevedra: Gondomar, Donas, 29TNG1758, $400 \mathrm{~m}$, on stump of Pinus radiata, together with Phaeolus schweinitzii, 10 Oct 2010, J.L. Tomé Ortega \& J. Prieto, LOU-Fungi 19485. Pontevedra, 29TNG2996, $50 \mathrm{~m}$, on stump of Pinus pinaster, 25 Oct 1989, J.B. Blanco-Dios, LOU-Fungi 4180. Pontevedra, Bora, 29TNG3397, $120 \mathrm{~m}$, on stump of Pinus pinaster, together with Phaeolus schweinitzii, 8 Oct 2012, J.B. Blanco-Dios, LOU-Fungi 19573 (holotype); ibidem, 24 Oct 2012, J.B. Blanco-Dios, LOU-Fungi 19574.

Other collections examined - Buchwaldoboletus lignicola - SPAIN. A Coruña: Ames, Bertamiráns, Caroubáns, 29TNH2847, 120 m, on stump of indeterminate species, 1 Oct 2000, I. Galarza \& J. Rodríguez-Vázquez, LOU-Fungi 15532 (sub Pulveroboletus hemichrysus (Berk. et Curtis) Singer (Rodríguez Vázquez \& Castro 2001)). Pontevedra: Salceda de Caselas, Entenza, 29TNG3657, 90 m., on stump of Pinus pinaster, 24 Oct 2003, J.B. Blanco-Dios, LOU-Fungi 19479; ibidem, 10 Nov 2004, J.B. Blanco-Dios, LOU-Fungi 19480; ibidem, 3 Nov 2005, J.B. Blanco-Dios, LOU-Fungi 19481 (Blanco-Dios \& Tomé Ortega 2011 [2009]).

\section{Discussion}

Buchwaldoboletus pontevedrensis is included in the stirps Lignicola, characterized by pileus and stipe tomentose, brown, reddish brown, dry, context yellow, bluing, especially above the tubes (Ortiz \& Both 2011). This new species is morphologically characterized by the following combination of features: (i) pileus fleshy, $130-198 \mathrm{~mm}$ broad, (ii) stipe attenuate to radicant, robust, up to $100 \times 71 \mathrm{~mm}$, (iii) basidiospores (6.5-) 7.5-10 (-11.2) × (2.8-) 3.5-4.5 (-5) $\mu \mathrm{m}, \mathrm{Xm}=9.3 \times 3.8$ $\mu \mathrm{m}, \mathrm{Vm}=69 \mu \mathrm{m}^{3}$, ovoid, ellipsoid to elliptic, (iv) versiform cystidia and caulocystidia, (v) end cells of pileipellis $14-170 \times 4-15.5 \mu \mathrm{m}, \mathrm{Q}=1.7-24.3$, cylindrical, clavate, broadly clavate or irregularly shaped, and (vi) habitat at the base of on top of stumps of Pinus pinaster and P. radiata.

Among the morphologically similar species, the closest taxon is Buchwaldoboletus lignicola. This related species differs specially in having smaller pileus (up to $120 \mathrm{~mm}$ broad), stipe up to $25 \mathrm{~mm}$ wide, cylindric or subcylindric, elliptic and slightly shorter basidiospores, cystidia fusiform or lageniform, end cells of pileipellis short, cylindraceous and caulocystidia fusiform or clavate (Breitenbach \& Kränzlin 1991, Bessette et al. 2000, Fernández et al. 2001, Muñoz 2005, Arrillaga et al. 2010). B. lignicola is widely distributed throughout Europe and Eastern North America and habitat at the base of or on top of stumps of conifers: Picea abies, Pinus sylvestris, $P$. strobus and other pines, also with Larix spp., rarely with deciduous trees (Prunus avium) (Muñoz 2005, Ortiz \& Both 2011), very often found together with the polypore Phaeolus schweinitzii (Fr.) Pat., (as often happens with B. pontevedrensis). The association of Buchwaldoboletus lignicola with the brown-rot Phaeolus schweinitzii is well-documented in the European literature (Jahn 1979; Szczepka \& Sokol 1984; Brown 1985; Lipka $(1985,1987))$.

\section{Proposed key to the taxa of Buchwaldoboletus in Europe}

1a. Pileus and stipe yellow to yellow-orange, pileus silky tomentose. Basidiospores 6.2-7.5 (9.5) $\times$ 3.2-4 $\mu \mathrm{m}, \mathrm{Xm}=6.9 \times 3.4 \mu \mathrm{m}, \mathrm{Q}=1.7-2(2.5)$, ovoid to ellipsoid B. sphaerocephalus 1b. Pileus brown, brown-ochre, brown-reddish, ochre-creamy, ochre-yellow, ochre-orange to yellow-orange and stipe predominantly sulfur yellow, yellow-ochre to yellow-brown. 2a. Pileus 25-120 mm broad, stipe cylindric or subcylindric, up to $100 \times 25 \mathrm{~mm}$. Basidiospores: $\mathrm{Xm}=7.5 \times 2.9 \mu \mathrm{m}, \mathrm{Vm}=27 \mu^{3}$, elliptic, cystidia fusiform or lageniform, caulocystidia fusiform or clavate and end cells of pileipellis cylindraceous, $20-40 \times 3.8-5.5 \mu \mathrm{m}, \mathrm{Q}=6.5-9 \ldots \ldots$ B. lignicola 2b. Pileus 130-198 mm broad, stipe attenuate to radicant, up to $100 \times 71 \mathrm{~mm}$. Basidiospores: $\mathrm{Xm}=$ $9.3 \times 3.8 \mu \mathrm{m}, \mathrm{Vm}=69 \mu \mathrm{m}^{3}$, ovoid, ellipsoid to elliptic, versiform cystidia and caulocystidia, and end cells of pileipellis cylindrical, clavate, broadly clavate or irregularly shaped, 14-170 $\times 4-15.5$ $\mu \mathrm{m}, \mathrm{Q}=1.7-24.3$ 


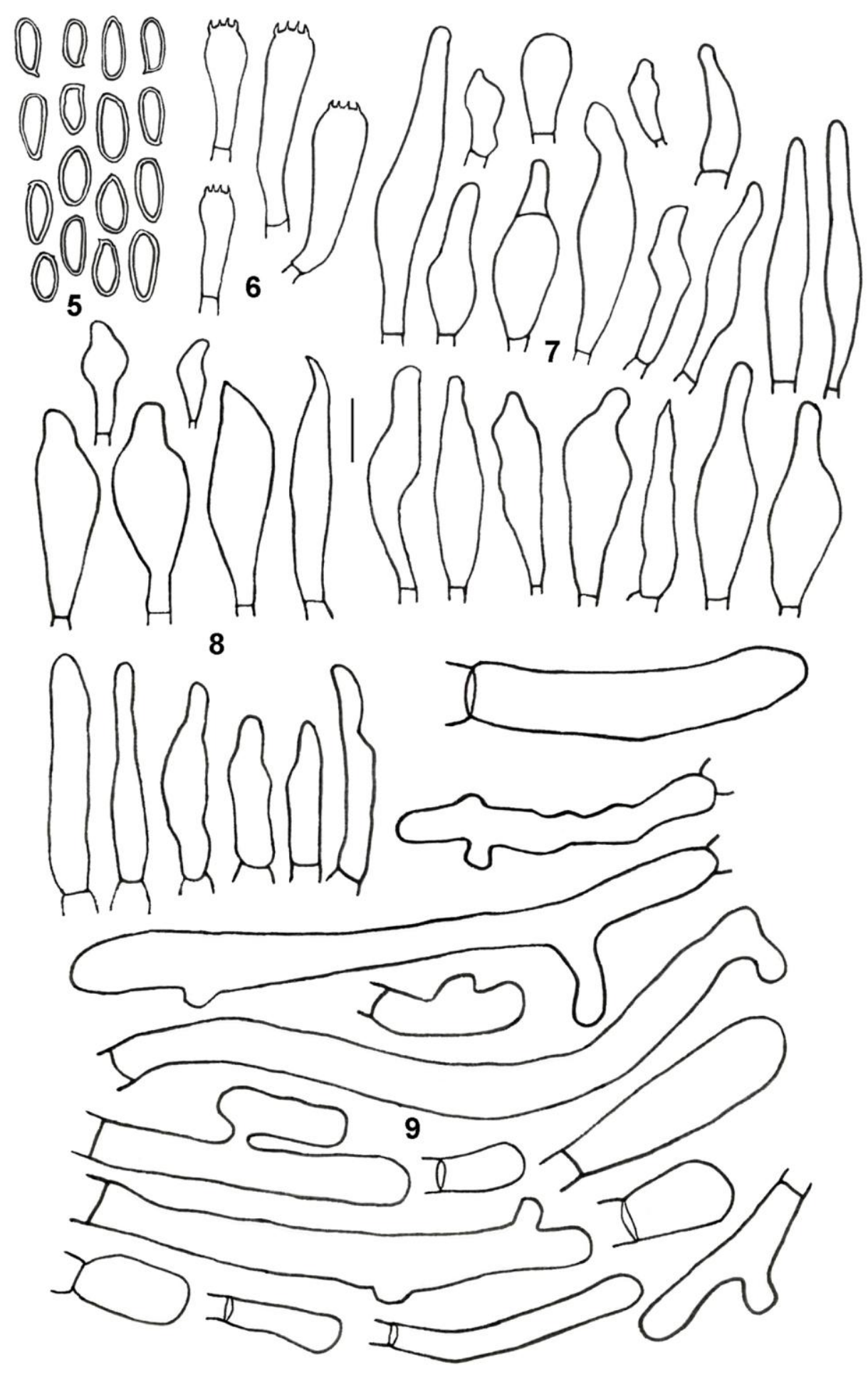

Figs 5-9 - Buchwaldoboletus pontevedrensis (holotype, LOU-Fungi 19573). 5. Basidiospores. 6. Basidia. 7. Cystidia. 8. Caulocystidia. 9. End-cells of pileipellis. Scale bar $=10 \mu \mathrm{m}$. 


\section{Acknowledgements}

We would like to thank to José Luis Tomé Ortega and Javier Prieto for sending us specimens and one photo of this new species, and Ignacio Galarza and José Rodríguez Vázquez for providing bouchers of Buchwaldoboletus lignicola. The author is grateful to Dr. Beatriz OrtízSantana and Jose Antonio Muñoz Sánchez for yours comments. Amancio Castro is greatfully acknowledged for providing technical assistance. We express the most sincere thanks to the director and members of the Centro de Investigación Forestal de Lourizán (Consellería do Medio Rural, Xunta de Galicia) for conserving the herbarium LOU-Fungi.

\section{References}

Arrillaga P, Ferreño J, Iturrioz JI. 2010 - Especies raras o poco conocidas de hongos macromicetos IV. Boletín Micológico FAMCAL 5, 65-76.

Bessette AE, Roody WC, Bessette AR. 2000 - North American boletes. A colour guide to the fleshy pored mushrooms. Syracuse University Press, New York, USA. 400 pp.

Blanco-Dios JB, Tomé Ortega JL. 2011 [2009] - Notas sobre o xénero Buchwaldoboletus en Galicia e Norte de Portugal (I). Mykes 12, 45-50.

Both EE. 1993 - The boletes of North America. A compendium. Buffalo Museum of Science. Buffalo, New York. 436 pp.

Breitenbach J, Kränzlin F. 1991 - Champignons de Suisse. Tome 3. 364 pp.

Brown RP. 1985 - Is there an association between Boletus lignicola and Phaeolus schweinitzii? Bulletin of the British Mycological Society 19, 61-63.

Fernández J, Pérez JL, Undagoitia J. 2001 - Pulveroboletus lignicola (Kallenbach) Pilát y Suillus viscidus (L.) Roussel: dos interesantes taxones hallados en el norte de la Península Ibérica.Yesca 13, 39-41.

Jahn H. 1979 - Pilze die an Holz wachsen. Busse Herford. 268 pp.

Ladurner H, Simonini G. 2003 - Xerocomus s.l. Fungi Europaei 8. 527 pp.

Lipka J. 1985 - Weiteres über Buchwaldoboletus lignicola (Kallenbach) Pilát und Phaeolus schweinitzii (Fries) Patouillard. Zeitschrift für Mykologie 51(1), 47-50.

Lipka J. 1987 - Beitrag zur Kenntnis der Variabilität, Ökologie and Phänologie des Buchwaldoboletus lignicola. Beiträge zur Kenntnis der Pilze Mitteleuropas III, 63-66.

Muñoz JA. 2005 - Boletus s.l. (excl. Xerocomus): Strobilomycetaceae, Gyroporaceae, Gyrodontaceae, Suillaceae, Boletaceae. Fungi Europaei 2 [2nd edition]. 952 pp.

Ortíz-Santana B, Both EE. 2011 - A preliminary survey of the genus Buchwaldoboletus. Bulletin of the Buffalo Society of Natural Sciences 40, 1-14.

Rodríguez Vázquez J, Castro ML. 2001 - Fragmenta chorologica occidentalia, Fungi, 7700-7727. Anales Jard. Bot. Madrid 59 (1), 139-141.

Singer R. 1965 - Die Röhrlinge, Teil I. Die Boletaceae. Die Pilze Mitteleuropas, Band V. 131 pp + $21 \mathrm{pl}$.

Szczepka MZ, Sokól S. 1984 - Buchwaldoboletus lignicola (Kallenb.) Pilát and Phaeolus schweinitzii (Fr.) Pat. - das Problem ihres gemeinsamen Auftretens. Zeitschrift für Mykologie 50(1), 95-99.

Watling R, Hills AE. 2005 - British Fungus Flora. Agarics and Boleti. 1. Boletes and their allies. Royal Botanic Garden, Edinburg. 172 pp. 